E $\quad F \quad$ EF

\title{
Teacher-student relationship and its impact on students' desire for knowledge
}

Ruzhena Voynova ${ }^{a^{*}}$

Suggested Citation:

$T$

and Issues Proceedings on Humanities and Social Sciences.

Abstract

T E TTF

F EF Ruzhena Voynova

$\mathrm{F}$

E-mail address 
Proceedings on Humanities and Social Sciences.

\section{The school in the context of postmodern society}

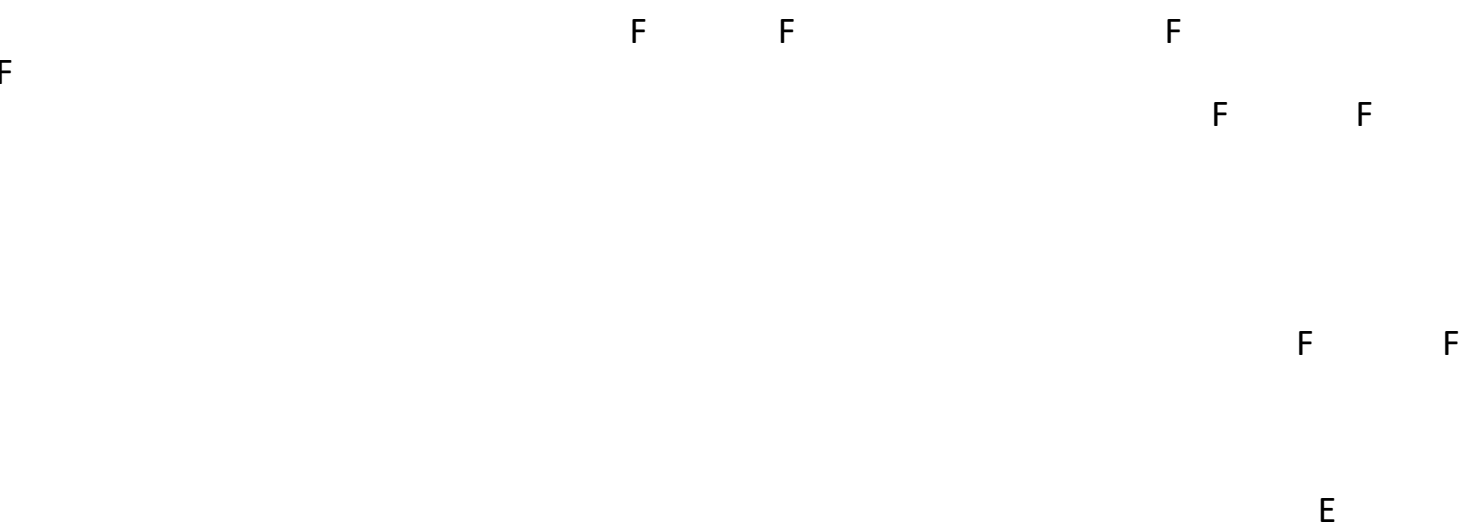

$E$ is well known that they (teachers) know that if the student continues like that, they will send him away and this is it, he is no longer a problem for them."; "If someone fails in the education system, he is rejected." 


\section{Research Project SDropSy} opinion, do not assume their role as professor. When you're a professor, in my opinion, you should love your job, you should make us want to learn."

\subsection{Methodology}

\section{$\mathrm{E}$}

am passionate about my work, I want to see them (

succeed

He did it very well, his teaching, he was brilliant because he marked a problem for example on the board and if, if the students needed an hour to solve it, he let them this time to solve it 
Proceedings on Humanities and Social Sciences.

\subsection{The relation to knowledge}

By the end, is it important that they know how to solve an equation or is it more important to have social skills than knowledge?

2.3. The desire for knowledge and the desire to transmit the knowledge

$\mathrm{F}$

My favorite teachers, you could see that they like their job. It really encourages you to want to go into their class."

If the teacher is 
Proceedings on Humanities and Social Sciences.

involved as a teacher and wants to do well his course and everything ... and after there is no ... class response or even ... that also discourage them

\subsection{Teacher-student relationship and its effect on students' desire for knowledge}

"I like that the teachers of languages tell me that I

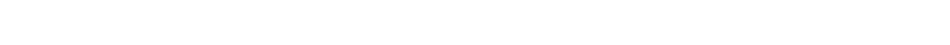


Proceedings on Humanities and Social Sciences.

really well together. $\mathrm{F}$

Teachers do not always have reasons, students are not always right, I think we have to hold together and try to sustain each other."

\section{To becontinued...}

\section{References}

Télémaque, 1,
$\mathrm{M} \quad \mathrm{E}$
Journal of School Psychology,

$\mathrm{F}$

Journal of Personnel Evaluaiton in

Education, 21

E Au risque d'enseigner.

E

$$
\mathrm{E}
$$

Analyse des pratiques des enseignants debutants.

Approches didactiques.

$\mathrm{M}$

$\mathrm{E}$

$\mathrm{F}$

Revue française de pedagogie,

F

Levels of autonomy and responsabilities of teachers in Europe.

$\mathrm{F}$

E

Et toujours ${ }_{\mathrm{F}}$ le desir nous rendait soucieux. T

E T

Pedagogik,

La vraie vie a l'ecle. $\mathrm{F}$

$\begin{array}{cl}\mathrm{M} & \text { Les ecrits. } \\ \mathrm{M} & \text { Le Seminaire Livre XX (1972-1973). } \\ \mathrm{E} & \mathrm{T}\end{array}$

Urban Education,

Ela. Etudes de linguistique appliquee, 
Proceedings on Humanities and Social Sciences.

M

M

Revue française de pedagogie,

Margrit Stamm blog. T

$\mathrm{E}$

M Transformationen im Ausbildungsprozess.
Revue Projet,

M Der Bezug zum Wissen in der Lehrerbildung: Eine psychoanalytische Studie zu 